Western University Scholarship@Western

1997

\title{
More on Hawtrey, Harvard and Chicago
}

David Laidler

Follow this and additional works at: https://ir.lib.uwo.ca/economicsresrpt

Part of the Economics Commons

Citation of this paper:

Laidler, David. "More on Hawtrey, Harvard and Chicago." Department of Economics Research Reports, 9704. London, ON:

Department of Economics, University of Western Ontario (1997). 
ISSN:0318-725X

ISBN:0-7714-1970-8

\title{
RESEARCH REPORT 9704
}

More on Hawtrey, Harvard and Chicago

by

David Laidler

March 1997

\author{
Department of Economics \\ Social Science Centre \\ University of Western Ontario \\ London, Ontario, Canada \\ N6A 5C2 \\ econref@sscl.uwo.ca
}




\title{
MORE ON HAWTREY, HARVARD AND CHICAGO*
}

\author{
by
}

\author{
David Laidler
}

"Without implicating them in the views I express, let me acknowledge helpful conversations and correspondence with Milton Friedman, Dan Hammond, Perry Mehrling, Roger Sandilands, Frank Steindl and George Tavlas. My correspondence with Don Patinkin was brought to an end by his untimely death in 1995. Let this paper stand as a small personal tribute to a sometime colleague, great friend, and magnificent scholar. The financial support of the Lynde and Harry Bradley foundation, and of the SSHRCC are gratefully acknowledged. 


\section{INTRODUCTION}

In Laidler (1993) I drew attention to the fact that Milton Friedman's views on monetary factors in the business cycle are close to those espoused by Ralph Hawtrey in the 1920s and 1930s, (as indeed are his opinions on the relative effectiveness of monetary and fiscal policy though I did not discuss this issue in the paper in question). I further showed that Allyn Young, who taught monetary economics at Harvard until 1927. did much to bring Hawtrey's ideas into American discourse in the 1920s; that Lauchlin Currie. Young's student and Hawtrey's assistant during the latter's tenure of a visiting appointment at Harvard in 1928-29, came closer to anticipating some of Friedman's major conclusions about the role of monetary factors in the "Great Contraction" of 1929-33, than did any Chicago economist of the period; and that one of the prime contributions cited by Friedman (1974) in his discussion of the links between his own work and an earlier "Chicago tradition", namely the manifesto that emerged from the winter 1932 Harris Foundation conference, was drafted by a committee that included John H. Williams, also a Harvard professor, who contributed a paper to the Conference Volume justifying that manifesto, and who, as a result of Young's death in 1929, had supervised the Ph.D thesis out of which most of Currie's significant publications on these matters developed.' I concluded. on the basis of this evidence. that the "Chicago tradition" invoked by Friedman was not unique to that University in the early 1930s, but had strong and direct links to Harvard and. by that route, indirect links to Hawtrey too.

This conclusion has recently been criticised by George Tavlas (1997), who takes me to task, among other things, for neglecting contributions of the Chicago economist, Paul Douglas, writing both alone and in collaboration with Aaron Director, to the Chicago tradition. The significance of this aspect of Tavlas' critique stems from the fact that Douglas started writing on these matters in the later 1920s, and that his book with Director appeared in 1931. If Douglas is a key contributor 
to Friedman's Chicago tradition, then, it has an earlier origin at that University than 1932 or thereabouts. In this paper, I shall answer many of Tavlas criticisms, and in the course of doing so, present a little new evidence that bears on the major points of contention between us.

In the following pages, I shall discuss in turn: the views of Hawtrey (eg. 1925) and Friedman (eg. 1974) on the powers of monetary and fiscal policy, and contrast them with those of Douglas and Director (1931) to which Tavlas draws attention; the role of monetary factors in causing and exacerbating the Great Contraction of 1929-1933, and what monetary policy might have accomplished to mitigate it, as seen by Hawtrey (1932), Currie (1934a \& b), Friedman and Schwartz (1963) and Douglas $(1933,1935)$; and the relationship between Douglas' work and that of some of his Chicago colleagues. I shall conclude that the skepticism I expressed in (1993) about the uniqueness in the early 1930s of a Chicago tradition to which Friedman's work is related remains well justified.

Before proceeding to the substance of my case, however, let me explicitly set aside two matters. First, disagree though I do with Tavlas on many issues, his treatment of Douglas in particular, there is nevertheless much to admire in his paper, not least his discussion of the hitherto unappreciated contribution of Aaron Director to the Chicago tradition, and his analysis of the evolution of Jacob Viner's work. Second, there are two important aspects of Friedman's work whose antecedents are not in contention, namely his advocacy of rule guided monetary policy and his careful and systematic empiricism. Neither Hawtrey nor Currie, nor Young for that matter, favoured governing monetary policy by rules. As Humphrey (1971) showed, some non-Chicago economists did advocate such measures in the 1920s and 1930s, but I have no doubt that Friedman's position on monetary rules, and his linking of it to a liberal (in the old fashioned sense) political agenda, derived from the Chicago tradition in general and Henry Simons' contribution to 
it in particular. Nor, despite the fact that Young and Currie did carry out important and systematic empirical work, do I see any reason to doubt J. Daniel Hammond's (1996) contention that Friedman's own empiricism derives primarily from the NBER tradition of Wesley C. Mitchell and Arthur F. Burns.

\section{FRIEDMAN, HAWTREY, AND DOUGLAS AND DIRECTOR ON FISCAL POLICY}

Tavlas relates Friedman's views on fiscal and monetary policy to those of Douglas and Director (1931). They are most succinctly set out in his reply to James Tobin's criticisms of his position on these matters. contained in Gordon (ed.) 1974, (pp. 137-143). Friedman's argument may be paraphrased, in terms of an IS-LM schema, as follows: government expenditure financed by borrowing from the public will shift the IS curve to the right, and mainly affect interest rates; only to the extent that the LM curve deviates from the vertical will the level of money income be increased. If, on the other hand, government expenditure is financed by money creation, then the LM curve will also shift to the right, inducing a much more significant increase in money income. This analysis provides the context of Friedman's remark, quoted by Tavlas (1997. p.197) that the deficit's ". . .monetary effect is 'alchemy of a much deeper significance' than the fiscal effect" (Friedman 1974, p. 141). This comment does not derive, as Tavlas would have it. from any tradition developed at, and unique to, Chicago. Rather it is an expression of the so-called "Treasury View" developed by Hawtrey. (See Hawtrey 1925 in particular). Friedman deviates from John Hicks' (1937) original IS-LM characterisation of that view only in allowing the logical possibility that the LM curve might not be completely vertical; an effect whose empirical significance he clearly thought trivial. ${ }^{2}$ 
It was Hawtrey's contention that bond financed public expenditure would normally do no more than displace private sector expenditure, because ". . it is only in exceptional circumstances that Government expenditure on public works will itself bring about an increase in velocity" (Hawtrey 1929, p. 637), while money financed expenditure would be effective, but only because it increased the money supply. According to Hawtrey, if the money supply was increased by the same amount as was needed to finance a public works program. but by other means, the effects on aggregate demand would usually be the same. ${ }^{3}$ Hawtrey's conclusions here, so close to Friedman's, differ in emphasis, but crucially so, from those of Douglas and Director, to which Tavias (1997) relates Friedman's position. The latter argued that, although in the case of either tax or bond financed public works expenditure, it was necessary to allow for some offsetting reduction in private demand caused by these methods of finance, the overall effect would definitely be "a net addition to the demand for labor" (Douglas and Director 1931 p. 210). Noting that "Where the funds for government expenditures come directly or indirectly from an increase in the total supply of bank credits, even Mr. Hawtrey has admitted the possibility of increasing the demand for labor by the construction of public works" (p. 210) they also concluded that ". . it is possible for government to increase the demand for labor without a corresponding contraction of private demand, and that this is particularly the case when fresh monetary purchasing power is created to finance the construction work." (pp. 210-211)

Tavlas (1997, pp. 203-204) suggests that, after 1931, Hawtrey became "increasingly pessimistic about the efficacy of government expenditures and more and more an advocate of central bank measures." (Tavlas 1997 p.204) All I can say to this is that I do not read Hawtrey this way, nor, as far as I can see, does his intellectual biographer Patrick Deutscher (1990, see particularly pp. 65-66, 217-219). On my reading, from 1913 until after the publication of the 
General Theory (Keynes 1936), Hawtrey never deviated from the view that government expenditures would normally be insufficient to combat unemployment, unless financed by money creation, and that anything they might accomplish if they were so funded could also be accomplished if the central bank put money into circulation by other means, specifically by open market operations, or by financing a deficit created by cutting taxes. He remained, that is to say, steadfast in his support of a position that Friedman would later hold, and which was not held at Chicago in the early 1930s; and even if Tavlas's contention on this point were correct, that would only mean that, with the passage of time. Hawtrey moved closer to the position that Friedman would later hold, and not away from it.

\section{MONETARY FACTORS IN THE GREAT CONTRACTION}

Friedman and Schwartz (1963, ch. 7) portrayed "The Great Contraction" of 1929-33 as "a tragic testimonial to the importance of monetary forces" (p. 300) and argued that "The failure of the Federal Reserve system to prevent the collapse reflected not the impotence of monetary policy, but rather the particular policies followed by the monetary authorities and, in smaller degree, the particular monetary arrangements in existence." (p. 300) They contrasted these conclusions with the then prevailing opinion that the Contraction had shown that orthodox "monetary policy is of extremely limited value in promoting stability" (p. 300). ${ }^{4}$

As I showed in 1993, the Chicago economists of the early 1930s were at best guarded about what could be expected of open market operations, noting for example that Viner (1932) was less confident in their powers than was John Williams (1932). Tavlas takes me to task for neglecting the Chicago economists' optimism about the expansionary potential of money financed deficits. He points out, correctly, that Douglas in particular was an advocate of such measures, and suggests that 
he influenced Aaron Director, Jacob Viner, and Henry Simons on this issue. Tavlas is right that advocacy of this unorthodox means of increasing the money supply did become an integral part of Chicago teaching, including that of Lloyd Mints, as the 1930s wore on. Patinkin (1969) provides ample evidence of this. The position in question is, however, conspicuous by its absence from the 1932 Harris Foundation conference manifesto, which Douglas did not sign, and to which Friedman, nevertheless, drew attention as an important document embodying the thought of members of the Chicago department. Since, it was my claim that the "hopefulness" which, in Friedman's view, characterised the Chicago tradition was more apparent in the contribution of Williams to that 1932 conference than that of any members of the Chicago department, and since I also noted that, for example, Viner did become a little more optimistic in 1933, I fail to see how Tavlas' arguments, correct as they may be, bear on this aspect of my case.

Douglas' advocacy of deficit finance as a means of increasing the money supply during, and even before (See Douglas 1927), the Great Contraction, hardly makes him a forerunner of Friedman and Schwartz (1963) either. The latter argue that orthodox monetary measures, particularly open market operations, could have done much to counter the Contraction. had they only been pursued with sufficient vigour. Douglas did not believe that, either during or after the event. Thus, Douglas and Director (1931 p. 243)) expressed considerable and, for the time, rather conventional, skepticism about the expansionary powers of open market operations in any slump. After 1932, moreover, Douglas explicitly argued that open market operations had been proven impotent by the events of that year. In (1933) he wrote about the open market operations of 1932 in the following terms: 
"The expectation was that the banks would be so choked with cash that they would have to increase their loans.

The hoped for results did not occur. It is not enough to give banks the power to create more credit. It is necessary that the loans should actually be made in large quantities. That did not happen because in a period of depression businessmen are afraid to borrow and banks are afraid to lend" (p. 10)

Contrast Douglas's position with the general view expressed by Ralph Hawtrey (1932, Ch.4) about what could be accomplished in a period of depression. Should what he called "a deadlock" arise in credit markets, it "can best be broken by injecting money into the system. Now the central bank has the power of creating money" (p. 172). Hawtrey did indeed believe, as Mints (1945), quoted by Tavlas (p. 204), would much later note, that such a situation would "not yield to a low bank rate", but this is beside the point in contention between Tavlas and myself, because it was also Hawtrey's position that, when

". . the bills offered and the suitable applications for advances are inadequate and do not increase enough, the banks have the alternative of buying long term investments of a suitable marketable character. . .

There must ultimately be a limit to the amount of money that the sellers will hold idle, and it follows that by this process the vicious circle of deflation can always be broken, however great the stagnation of business and the reluctance of borrowers may be" (1932 pp. 173-174). 
It is even more instructive to contrast Douglas's interpretation of the particular events of 1932, with that offered by Lauchlin Currie in (1934b).

"It has been held that security purchases by a central bank in the downswing of business will bring about an expansion of money. In 1932 the reserve banks bought an unprecedented amount of bonds and money did not expand. Therefore open market operations cannot bring about expansion in periods of depression. The answer to this line of argument is. of course, that the major premise as stated is incomplete. The assumption is that the purchases will result in an actual increase in member bank reserves. The open market policy of 1932 was offset by an outflow of gold and the liquidation of member bank indebtedness to the reserve banks so that only a comparatively small increase in reserves occurred." (p. 147)

Currie's conclusions then followed:

"Much of the current belief in the powerlessness of the reserve banks appears to arise from a complete misreading of the monetary history of 1929-32. It is generally held that the reserve administration strove energetically to bring about expansion throughout the depression but that contraction continued despite its efforts. Actually the reserve administration's policy was one of almost complete passivity and quiescence." (p. 147) 
"The drastic contraction of money from 1929 to 1932 proceeded automatically with no real effort made to offset it. Hence the course of events during this period should not be cited as evidence of the inability of a central bank to arrest contraction of money and bring about expansion" (1934b, p. 148, italics in original)

If any doubts remain about Currie's views as of 1934 on the role of monetary policy in the Great Contraction, they can surely be settled by referring to the title of the article in which, in that year, he summarised them: namely, "The Failure of Monetary Policy to Prevent the Depression of 1929-1932" (Currie 1934a).

Currie's monetary analysis of the Great Contraction was not brand new in 1934. Chapter IX of his Ph.D. thesis Bank Assets and Banking Theory, supervised by John H. Williams, and submitted at Harvard in January 1931, bore the title "Bank Assets and the Business Cycle". In this chapter he pointed to a "normal relation" of "movements in demand deposits . . to the business cycle" with "a contraction preceding the downturn in business in 1920, 1923, and 1929" (Currie 1931, p. 229), and he argued, with respect to Federal Reserve policy in 1929 and 1930, ". . that a much greater expansion of credit might have been brought about after the downturn in business in 1929 than did in fact take place" (Currie 1931, p. 237). ${ }^{5}$ Currie's discussion of American experience over the 1920-1930 period was. moreover, cast in terms of a monetary analysis of the cycle which, as he explicitly acknowledged. derived from Hawtrey, to whose theoretical views the first eleven pages (pp. 211-221) of this chapter are largely devoted.

The influence of Hawtrey on Currie has not been sufficiently appreciated, largely one suspects because he himself later downplayed it. Even in the version of his thesis submitted for the Wells Prize competition in October 1932, the first eleven pages of chapter IX (by then chapter XI) 
dealing with Hawtrey were deleted, and the subsequent discussion modified so that Keynes' Treatise on Money (1930), not published when this chapter was first drafted, as Currie explicitly pointed out in its first version, seemed to be the inspiration for its optimistic discussion of the powers of counter-cyclical monetary policy. ${ }^{6}$ But downplayed later or not, Hawtrey's influence on Currie is demonstrable and important.

In the course of criticising my 1993 paper. Tavlas, p. 201, quotes from a memoir written by Currie in 1978 and concludes on its basis that. while still at Harvard. Currie believed in "the inefficacy of open market operations and the need for budget deficits"; but Currie (1934a) was published just as Currie was leaving Harvard, and (1934b) after he had left. The passages I have quoted above from the second of these quite evidently contradict Tavlas's attribution of a belief in the inefficacy of open market operations to him while the title of the first refers to the failure, not the inability, of monetary policy to prevent the depression. Furthermore, Currie makes no mention of unbalanced budgets as a tool of expansionary policy in either work, nor does he do so in any of his other publications up to that date so far as I am aware. In the face of so evident a conflict between what Currie wrote while still at Harvard. and what he remembered more than forty years later, it is surely appropriate to rely on the contemporary source in establishing his views.

This is not to deny that Currie advocated unbalanced budgets as a means of fighting depression in his teaching at Harvard. He may well have done so, and in so doing he would have been taking up a position that his mentor Allyn Young had defended in the 1920s, as Mehrling (1994) has documented. It is, moreover, true that, as the 1930s wore on, and free reserves continued to build up in the banking system, Currie began to lose faith in the reliability of open market operations, and from 1935 onwards he did indeed become a very vigorous advocate of fiscal policy. Furthermore, Sandilands (1990) and Steindl (1996) have discussed his views in the later 
1930s, and have established that his explanation of the 1938 downturn in terms of fiscal policy is very different from Friedman and Schwartz's monetary explanation of this event. ${ }^{7}$ But, and more to the point of my disagreement with Tavlas, none of this can alter the fact that what Currie wrote in (1934b) was far closer to the (1963) views of Friedman and Schwartz on the role of monetary factors in the Great Contraction of 1929-1933 than anything written by Douglas or any of his Chicago colleagues, with the possible exception of Simons who, in a (1935) review of Currie (1934b) expressed broad agreement with his conclusions, which, he said were "firmly established in the "oral tradition' of some schools" (Simons 1935, p. 555).

\section{DOUGLAS AND THE CHICAGO TRADITION}

In (1993) I treated Paul Douglas only briefly, and as something of an outlier at Chicago, partly because of positions he took in his (1935) book Controlling Depression, but also because of his failure to sign the 1932 Harris Foundation conference manifesto. Tavlas, on the other hand, argues that he occupied an important place in the mainstream of that department's monetary thought. ${ }^{8}$ As it happens. Eric Lundberg was a visiting student at Chicago in 1931-32. the academic year immediately prior to Milton Friedman`s arrival there, and his (1934) report to the Rockefeller Foundation on his two year visit to the United States (September 1931-September 1933) has recently (1995) been published for the first time. It contains the following unflattering comment, which nevertheless identifies Douglas as a leading contributor to Chicago discussions of the cycle at that time:

"In the field of business cycle theory the University of Chicago had very little to offer. Professor Mints touched on some of the problems in his lectures on monetary 
theories, while Douglas offered a very simple overproduction and underconsumption theory." (Lundberg 1934, pub. 1995, p. 51 )

One might question Lundberg's overall assessment of the state of cycle theory at Chicago, because visiting graduate students do not, after all, necessarily learn all there is to be learned about a department. His characterisation of Douglas is. however, demonstrably accurate in the light of the written record.

Tavlas presents a (1927) paper by Douglas as an early exposition of the "Chicago" case for steady money growth. However, the case that Douglas makes is not based on any version of the quantity theory of money, but rather on the underconsumptionist theory of William T. Foster and Waddill Catchings, to whose "brilliant and suggestive writings" (Douglas 1927, p. 37) he pays explicit tribute. It is easy to confuse these two very different strands in American economic thought, because both do indeed call for regular injections of new money into the economy as the best means of stabilising it. ${ }^{9}$ However, the underconsumptionist doctrine developed by Foster and Catchings insists that, if it is to be effective in curing a chronic tendency of consumer expenditure to fall short of the nominal value of consumption goods coming onto the market, the new money in question must be placed in the first instance in the hands of consumers. That is exactly what Douglas argued in 1927, and would argue again in (1932, 1933 and 1935).

Tavlas points out that, in 1927, "Douglas advocated that the government undertake public works projects financed by money creation if 'proper safeguards could be provided to prevent inflation' (p. 42)" (Tavlas 1997, p. 190). This is correct as far as it goes, but Douglas also told his readers that public works expenditures would be effective because they 
"...would give purchasing power to the workers and stabilize the price level. Since the services of these public works would later largely be offered gratuitously to the public, they would not enter into the volumes of commodities offered for sale and hence would not cause a fall in the price level." (Douglas 1927, p. 41)

This is a quintessential underconsumptionist argument in the style of Foster and Catchings. Underconsumptionism went into temporary eclipse in Douglas and Director (1931), a fact which I am unable to explain, but which would merit further investigation. Thus the cycle theory presented there is best summarised as an eclectic amalgam of Pigou (1927) and Mitchell (1928). Tavlas (1997, p. 192) argues that in their treatment of this topic, Douglas and Director "... introduced into the Chicago literature the view that the cycle can be cumulative in nature". Since, however, that view was central to the cycle theories of J.S. Mill, Alfred Marshall, and a host of others, including of course Hawtrey, Mitchell and Pigou, there could hardly be stronger testimony than this to the derivative nature of Chicago's analysis of the cycle in the early 1930s. The case for steady money growth in Douglas and Director (1931) is motivated with reference to the empirical work of Willard Thorp (1926), as discussed by Mitchell (1928, pp. 407). This work appeared to show that secular deflation was associated with cycles whose depression phases were relatively long, and whose booms were relatively shortlived. and the theoretical arguments that Douglas and Director advance to explain why such results should be taken seriously have a greater affinity to the Tract on Monetary Reform (See Keynes, 1923, pp. 33-35), a book which they do cite but not in this context, than to anything in the writings of Foster and Catchings.

Be that as it may, Douglas's (1933) pamphlet Collapse or Cycle and his longer (1935) monograph Booms and Depressions return to the underconsumptionist theme. Though Foster and 
Catchings are not cited as they had been in (1927), Douglas's analysis is nevertheless clearly a variation on their's, adapted to conditions prevailing in the United States in the early $1930 \mathrm{~s} .{ }^{10}$

"The chain of revival runs primarily from the increased purchasing power of the consumers and greater demand by consumers to increased borrowings and bank loans, rather than from increased bank loans to business to greater purchasing power by consumers to increased purchases." (1933, pp. 10-11, italics added)

What is required to promote such revival, then, is "(1) the liberal financing of relief, and (2) extremely large expenditures on public works" (p. 11). Spending on relief is required to meet ". . . actual human needs"; but also, and crucially, it will satisfy "the necessity for increased purchasing power by consumers which will start the cumulative process of revival" (p. 11, italics added). Public works will also, following the argument of Keynes, as presented in The Means to Prosperity (1933), generate ". . a multiplicative effect in stimulating business" (p. 12) Douglas expected such a programme to be effective whether financed by bond issue or money creation, but "It should be realized that bonds require the payment of interest by the government while money does not. So if the issuance of money can be controlled, this would seem to be by far the more economical way." (p. 13)

Whatever may have been the views of his Chicago colleagues on these matters, it should be clear that Douglas was not here advocating fiscal deficits as merely a reliable means of increasing the money supply in conditions of what Hawtrey called a "credit deadlock". Rather he was advocating: first, putting money in the hands of consumers in order to enable them to increase their expenditure and hence alleviate the chronic underconsumption which he believed to be an 
inherent characteristic of a market economy: and second. setting a Keynesian multiplier process in motion by public works expenditures. Methods of finance, though not irrelevant. were of secondary importance to Douglas' programme, whereas. in the Chicago tradition as described by Patinkin (1969), they were all- important since the whole object of the exercise was to increase the quantity of money in circulation.

To be sure, in (1933) Douglas also advocated the goal of price stability once recovery had been achieved (see. pp. 14 ff.); and he made a brief case for what later came to be called "100 per cent money" (see pp. 19-20). " ${ }^{\prime \prime}$ However. though it is not immediately apparent from this pamphlet. it is quite clear from a book written a year earlier, namely The Coming of a New Party (1932) (see. ch. 4, and particularly pp. 102-106) that Douglas regarded these proposals as an integral part of a comprehensive socialist (albeit democratic) policy agenda that included a large role for planning, and would permanently and radically change American and economic and social life. None of this looks to me like the economic thought, or even the monetary thought, of someone whose work lay at the centre of an intellectual tradition whose principal exponent in the 1930s was Henry Simons. but also included Lloyd Mints, Jacob Viner not to mention Frank H. Knight. and would later produce Milton Friedman. Friedman himself (1974) refers to these four as exponents of the doctrines that influenced him while he was a student at Chicago. but he does not mention Paul Douglas.

Friedman's views are, as he himself has argued. most akin to those of Henry Simons. (See Friedman 1967, repr. 1969, and 1974), not least as revealed in the 1933 unpublished manuscript in which the "Chicago Plan" for 100 per cent. money was first fully articulated (Simons et al. 1933). The theory of the cycle there set out is a monetary one, very much in the spirit of Hawtrey. An increase in the price level brought about by monetary expansion is presented as the sine qua 
non of recovery, and an unbalanced budget is presented, not as expansionary in and of itself, but solely as the best way of engineering this result: "at the present time, increase of expenditures or reduction of taxes would be far more immediately effective toward raising prices than conversion of the federal debt into the non-interest-bearing form." (Simons et al. 1933, p. 12)

Furthermore, Simons himself made it abundantly clear the following year that he regarded such measures as an integral part of an altogether broader Positive Program for Laisser Faire. (See Simons 1934). Though his program was a radical one, embodying a vigorous use of anti-trust measures and a significant degree of redistribution too, and hence differed from the. in many ways, more traditional agenda that we nowadays associate with Freidman, it was nevertheless far closer to what we have come to think of as a "Chicago" position than anything that Douglas would offer in the 1930 s.

\section{CONCLUDING COMMENT}

Friedman's monetary economics is certainly related to ideas that were current at the University of Chicago in the 1930s: that is not in dispute. However, there were sharp divisions among the Chicago economists of that time. Friedman himself has particularly stressed his indebtedness to Simons, but I have been unable to find a single reference to Paul Douglas in his monetary writings. The contemporary record gives us good reason to trust his judgement here.

However, in a number of key respects. Friedman's monetary theory of the cycle in general, as well as his position on the relative efficacy of monetary and fiscal policy, place him closer to Hawtrey than to any of his Chicago predecessors, and Hawtrey's analysis of these matters was fully developed long before the "Chicago Tradition" had come into being. Moreover, Friedman's specific views on the causes of the Great Contraction were more closely anticipated by Lauchlin Currie, a 
graduate student and instructor at Harvard. than by anyone else writing in the early 1930s: Hawtrey`s most important American advocate was Allyn Young. a professor at Harvard until 1927; and the only academic appointment Hawtrey ever held was at Harvard in 1928-29. where his assistant was Lauchlin Currie. Moreover. John H. Williams. the supervisor of Currie's doctoral dissertation had a major hand in drafting the 1932 Harris Foundation conference manifesto. which Friedman has cited as an important and early manifestation of 1930s Chicago thought. In the light of all this I am still inclined to suggest that there was a Hawtrey-Harvard connection to the origins of the 1930s Chicago tradition:: 


\section{FOOTNOTES}

'It should be pointed out that I am not the only one to raise most of these matters. On the similarity between Hawtrey and Friedman, see, for example, John R. Presley (1986); on Hawtrey's influence in America, and Young's role in promoting it, see Patrick Deutscher (1990, pp. 195-199) and Perry Mehrling (1994); and on Currie's anticipation of Friedman, see, inter alia, Karl Brunner (1968), Thomas Humphrey (1971) and Roger Sandilands (1990).

'See Hicks (1937, repr. 1967, p. 133, fn.1).

${ }^{3}$ This would also happen in the case of expenditure financed by borrowing abroad. "The desired end can be achieved by dropping out the expenditure on development works, and using the proceeds of the loan to extinguish government floating debt in the hands of the banks and the money market" (Hawtrey 1932, Ch. 8 p. 438). This chapter was originally prepared in 1930 as evidence to the Macmillan Committee.

${ }^{4} \mathrm{I}$ add the qualifier "orthodox" here, because, as did I in 1993, Friedman and Schwartz employ the phrase "monetary policy" in the usual sense of discount policy and open-market operations, rather than in the broader sense favoured by Tavlas, which also encompasses the finance of government expenditure by money creation.

${ }^{5}$ Note that Currie here discusses demand deposits rather than the money stock. Steindl (1996, Ch. 4) draws attention to this difference between his analysis and that of Friedman and Schwartz (1963).

${ }^{6}$ Currie's reasons for making this change are unknown. I am indebted to Roger Sandilands for helpful correspondence and for providing me with a copy of the relevant section of the 1932 version of Currie's thesis. 
${ }^{7} \mathrm{I}$ discussed aspects of this matter in Laidler (1993, p.1071, fn. 4, and p. 1088, fn. 21.). Note that Currie's post-1935 advocacy of fiscal policy " is based on an analysis which stress:d the possibility that the issue of government bonds would provide instruments which banks could purchase, thereby mobilising their excess reserves and increasing the money supply, rather than on a simple multiplier theory. I am indebted to Roger Sandilands for helpful correspondence on this point.

${ }^{8}$ Tavlas (1977) has earlier made the case for Douglas as an important contributor to the Chicago School. In preparing Laidler (1993) I simply overlooked this paper. I owe apologies both to Tavlas and my readers for this oversight. Had it not occurred, I might well have included a brief explanation of why I disagreed with Tavlas about Douglas at the point at which the latter came into my story.

${ }^{9}$ Tavlas (1997, p. 188) includes Foster and Catchings among the non-Chicago predecessors of Friedman, and has argued that case in more detail in (1976). A little later, writing with Joseph Aschheim (Tavlas and Aschheim, 1981) he refers to Foster and Catchings as "American Quantity Theorists" (p. 76). Thus, lying behind my disagreement with Tavlas about the place of Douglas in the Chicago tradition, is another about the place of Foster and Catchings in American Monetary Thought. For a discussion of Foster and Catchings as exponents of underconsumptionism, see, for example, Lawrence Klein (1966, pp. 138-140).

${ }^{10}$ Compare Douglas's views to Foster and Catchings (1925), p. 364: "The chief economic need, therefore, is a flow of money to consumers sufficient to provide for the necessary growth in their savings, and yet enable them to buy, and to continue to buy at an appropriately stable price level, all the goods that are actually ready for final consumption" (italics in original) See also Foster and Catchings (1925, pp. 338-339). 
${ }^{11}$ There is some inconsistency in Douglas's 1933 analysis, since he also advocates a secularly balanced, or even surplus, budget. Douglas did get this point straight two years later: see (1935), p. 185, fn.8.

${ }^{12}$ This is not to say that I accept Tavlas' (1997, pp. 199) suggestion that in (1993) I painted a picture of "a small, but vibrant, group of economists at Harvard working on relevant monetary issues until 1934." My assessment of that Department's contributions was a good deal more mixed than that. (See Laidler 1993, p. 1077 et seq.). Nevertheless, in Spring and Summer, 1933, Eric Lundberg seems to have found Harvard having more to offer by way of discussions of the business cycle than Chicago a little earlier. He singled out Professor (sic) Currie for special mention in this regard. See Lundberg (1934, 1995, p. 62). 


\section{REFERENCES}

Brunner, Karl. "Introduction" In Supply and Control of Money in the United States by Lauchlin Currie. New York, Russell \& Russell, 1968

Currie, Lauchlin. Bank Assets and Banking Theory. Unpublished Ph.D. Thesis, Harvard University 1931 (revised 1932).

. "The Failure of Monetary Policy to Prevent the Depression of 1929-32." J.P.E. 42 (April 1934: 145-77 (a)),

. The Supply and Control of Money in the United States. Cambridge, Mass.: Harvard Univ. Press, 1934. (b) Reprint. New York: Russell \& Russell. 1968.

Deutscher, Patrick. R. G. Hawtrey and the Development of Macroeconomics London, Macmillan, 1990.

Douglas, Paul H. "The Modern Technique of Mass Production and Its Relation to Wages" in Parker T. Moon (ed.), Stabilizing Business. Proceedings of The Academy of Political Science in the City of New York, 12 (No. 3) July 1927, 17-42.

. The Coming of a New Party. New York, Whittlesey House. 1932.

- Collapse or Cycle. Chicago: American Library Association. 1933.

. Controlling Depressions. New York: Norton, 1935.

and Director, Aaron. The Problem of Unemployment. New York: Macmillan, 1931.

Foster William T. and Catchings, Waddill. Profits. Boston and New York: Houghton Mifflin, 1925.

Friedman Milton. "The Monetary Theory and Policy of Henry Simons." J. Law and Econ 10 (October 1967): 1-13. Reprinted in The Optimum Quantity of Money and Other Essays. London: Macmillan, 1969. 
"Comments on the Critics". In Milton Friedman's Monetary Framework: A Debate with

His Critics, edited by Robert J. Gordon. Chicago: Univ. Chicago Press, 1974. and Schwartz, Anna J. A Monetary History of the United States, 1867-1960. Princeton

N.J.: Princeton Univ. Press (for NBER) 1963.

Hammond, J. Daniel. "Labels and Substance: Friedman's Restatement of The Quantity Theory," mimeo, Wake Forest University, Sept. 1996

Hawtrey, Ralph. G. "Public Expenditure and the Demand for Labour," Economica 5 (March 1925). 38-48.

. Currency and Credit. London: Longmans, Green \& Co., 1927.

. "The Monetary Theory of the Trade Cycle" EJ 39 (September 1929), 636-42.

. The Art of Central Banking. London: Longmans, Green \& Co., 1932.

Hicks, John R. "Mr. Keynes and the Classics: A Suggested Interpretation," Econometrica 5 (April 1937). Reprinted in Critical Essays in Monetary Theory. London: Oxford University Press, 1967.

Humphrey, T. M. "Role of Non-Chicago Economists in the Evolution of the Quantity Theory in American 1930-1950," Southern Economic Journal 38 (July 1971), 12-18.

Keynes, John Maynard. The Means to Prosperity. London: Macmillan, 1933.

. The General Theory of Employment, Interest and Money. London: Macmillan, 1936.

Klein, L. R. The Keynesian Revolution (2nd ed.) London: Macmillan, 1966.

Laidler, David. "Hawtrey, Harvard, and the Origins of the Chicago Tradition." J.P.E. 101, (December 1993), 1068-1103.

Lundberg, Erik. "Report of My Studies as a Rockefeller Fellow of Economics" (1934) in Studies in Economic Instability and Change. Stockholm: SNS Foerlag, 1995. 
Mehrling, Perry. "The Monetary Thought of Allyn Abbott Young," Working Paper \#94-04, New York: Barnard College (mimeo).

Mints, Lloyd W. A History of Banking Theory in Great Britain and the United States. Chicago: Univ. Chicago Press, 1945.

Mitchell Wesley C. Business Cycles: The Problem and its Setting. New York: NBER, 1928.

Patinkin, Don. "The Chicago Tradition, The Quantity Theory, and Friedman," Journal of Money, Credit and Banking 1 (February 1969) 46-70.

Pigou, Arthur C. Industrial Fluctuations. London: Macmillan, 1927.

Presley, John R. "Modern Monetarist Ideas: a British Connection". In R. D. Collison Black (ed.), Ideas in Economics. London: Macmillan, 1986.

Sandilands, Roger J. The Life and Political Economy of Lauchlin Currie: New Dealer, Presidential Advisor, and Development Economist. Durham N.C.: Duke Univ. Press, 1990.

Simons Henry C. A Positive Program for Laisser Faire: Some Proposals for a Liberal Economic Policy. Public Policy Pamphlet no. 15. Chicago: Univ. Chicago Press, 1934.

. Review of The Supply and Control of Money in the United States. by Lauchlin Currie J.P.E. 43 (August 1935): 555-58.

et al. "Banking and Currency Reform" Manuscript. Chicago: Univ. Chicago, 1933.

Steindl, F.G. Monetary Interpretation of the Great Depression. Ann Arbor: University of Michigan Press, 1996.

Tavlas, George. "Some Further Observations on the Monetary Economics of Chicagoans and NonChicagoans," Southern Economic Journal 43 (April 1976), 685-692. . "The Chicago Tradition Revisited: Some Neglected Contributions: Senator Paul Douglas (1892-1976)," Journal of Money, Credit and Banking 9 (November 1977): 529-38. 
. "Chicago, Harvard and the Doctrinal Foundations of Monetary Economics," Journal of

Political Economy 105 (February 1997), 185-209. and Aschheim. J. "The Chicago Monetary Growth-rate Rule: Friedman and Simons

Reconsidered," Banca Nazionale del Lavoro Quarterly Review 136 (March 1981), 75-89. 